\title{
The Church in Zimbabwe's Peace and Reconciliation Process under the Government of National Unity
}

\author{
Douglas Munemo and Elinah Nciizah
}

\begin{abstract}
On 15 September 2008, the Global Political Agreement (GPA) was signed between Zimbabwe African People's Union Patriotic Forum(ZANU PF) and the (Movement for Democratic Change) MDC formations to resolve the socio-economic and political crisis that engulfed Zimbabwe from 2000. The agreement paved the way for the formation of a Government of National Unity (GNU) in February 2009. The GNU provided an opportunity for the state to embark on a new national healing and reconciliation process. The process has however been championed by the government subsequently marginalizing of the church and other civil society groups. Christianity is the dominant religion in Zimbabwe accounting for more than eighty percent of the population. That makes the church perhaps the largest and arguably the most socially influential institution in Zimbabwe. As such, the church is expected to play a significant role in Zimbabwe's reconciliation process but its role has been peripheral. The study theoretically analyses the part played by the church in promoting peace, unity and healing in Zimbabwe under the GNU. It accomplishes this through the lens of Lederach's conflict transformation framework.
\end{abstract}

Key words: Reconciliation, Peace, Church, Crisis

\section{Introduction}

The search for peace and reconciliation in Zimbabwe has a long history which has been influenced by events dating back to the pre-colonial period through the colonial era to the post-colonial period. At independence the nation erred to think that the injustices and the oppression under colonialism could be forgiven and forgotten but events at the beginning of new millennium proved Zimbabwe wrong.

The origins of the Zimbabwean crisis have been the subject of much debate and contestation but scholars are generally agreed that since the year 2000, political violence, torture, human rights abuses, violence, inflation, unemployment among other elements of direct and indirect violence pervaded the Zimbabwean state generating what has come to be acknowledged as the Zimbabwe crisis.

Since colonial times the church has involved itself in peace processes. Under colonial rule the church promoted peaceful and harmonious existence between various racial and social groups in society. Despite this, the role of the Church in relation to the state was questionable. It played an active role in the war of liberation denouncing racial segregation, human rights abuses and other excesses of the state. It was targeted by the state for providing moral and diplomatic support to African nationalists who struggled against injustice from the white minority regime. In the post-colonial period the Church has been married to the oppressed people in the fight against colonial repressive laws and elements promoting human rights at times inviting the wrath of the state security apparatus and government officials.

The Church has in the crisis era been pushed to the margins of the peace and reconciliation process. The process has been dominated by institutions created by politicians like the Organ on National Healing, Reconciliation and Integration (ONHRI) and the Joint Monitoring and Implementation Committee (JOMIC). Political hegemonic struggles have pervaded these institutions that have advanced partisan interests ahead of national issues such as processes that promote social trust, reconciliation and healing. The work of the church premised on the encouragement of the above which is in tandem with Lederach's conflict transformation framework that seeks sustainable peace and reconciliation.

\section{Theoretical and Conceptual Issues}

Galtung (1990) defines peace as a political condition that ensures justice and social stability through formal and informal institutions, practices, and norms. Galtung identifies several conditions that must be met for peace to be reached and maintained. Among them is a need for recognised and valued interdependent relationships among groups fostering long-term cooperation during periods of agreement, disagreement, normality, and crisis. This definition of peace is apt because it recognises that social justice and interdependence are integral for peace to prevail yet these elements have not been fostered in Zimbabwe thus compromising the search for peace, reconciliation and unity.

Galtung (1989) argues that there is a distinction between negative peace and positive peace. To him, 
negative peace refers to a situation when something undesirable has stopped happening such as when oppression ends. Imposed peace accords and the deployment of peace keeping troops are associated with this type of peace. Positive peace describes a situation where there is the building and restoration of healthy relationships amongst parties to the conflict and the creation of social systems that serve the needs of the whole population and the constructive resolution of conflict. Positive peace implies a proactive process that deals with structural violence that underlies the conflict. Positive peace takes a long term view of conflict and highlights the fact that peace is fundamentally aimed at transformation of the relationships, issues, and causes that undergird the conflict

Our conceptualisation of peace should not be limited to the mere absence of violence for peace can be negative. Where there is negative peace structural violence is likely to exist. Structural violence refers to violence that is embedded in social and political hierarchies that impose conditions which place people at high risk of negative consequences, such as low wages, landlessness, illiteracy, poor health, nonexistent political representation and marginalization (Cheru:2002). Structural violence is a process which can breed direct violence which is an event. Direct violence refers to the physical harm perpetrated on an individual. Structural violence thus breeds negative peace and direct violence although negative peace is a preferred alternative to direct violence. Unlike negative peace, positive peace seeks to eliminate structural violence and direct violence while fostering unity and development. It involves creating structures which provide increasing degrees of political liberty and social justice.

Clark (2008) defines reconciliation as rebuilding of fractured individual and communal relationships after conflict, with a view encouraging meaningful interaction and cooperation between former antagonists. To him reconciliation entails much more than peaceful coexistence it requires the reshaping of parties' "relationships, to lay the foundation for future engagement between them"

Bloomfield (2003) perceives reconciliation as both a process and a goal; he sees it as a "dynamic, adaptive processes aimed at building and healing". Bloomfield (2003:12) states that,

Reconciliation is an over-arching process which includes the search for truth, justice, forgiveness, healing and so on. At its simplest, it means finding a way to live alongside former enemies - not necessarily to love them, or forgive them, or forget the past in any way, but to coexist with them, to develop the degree of cooperation necessary to share our society with them, so that we all have better lives together than we have had separately.

Badza and Chigwida (2005: 32-35) concur with Bloomfield, they perceive reconciliation as finding a way to make two or more ideas, situations agree with each other, when actually they seem to be in opposition. It involves making parties to conflict establish amity after a period of quarrelling and to accept a situation because there is nothing that can be done to change it. Badza and Chigwida identify three stages in the process of reconciliation namely acknowledgement; when perpetrators acknowledge wrongs committed, contrition; when perpetrators take responsibility for past actions to express regret and to directly request forgiveness from victims and finally forgiveness; which is the victims voluntary forgiveness of past injuries.

There is thus no universally accepted definition of reconciliation in conflict discourse. The researcher will adopt the definition from the International Year for Reconciliation (1998b), that refers to reconciliation as a profound process of dialogue between conflicting parties, leading to the recognition of the "other" and respect for his or her differences, interests and values. These are aspects that the Church fosters and promotes in its social mission of building and preserving mutually beneficial relations and interactions amongst citizens.

Closely related to the process of reconciliation is healing which Hamber (2003) defines as any strategy process or activity that improves the psychological health of individuals following extensive violent conflict. To him these strategies or activities aimed at rehabilitating and reconstructing local and national communities should be integrally linked to this process. The idea to Hamber is to restore normalized everyday life that can recreate and confirm people's sense of being and belonging.

Reconciliation and peace processes presuppose conflict, it is therefore important that conflict is defined. According to Kriesberg (2003) conflict is an antagonistic relationship between two people or parties, an expressed struggle between at least two interdependent parties who perceive incompatible goals scarce resources and interference from the other party in achieving their goals. Conflict can also be understood as a natural social consequence of fundamental change and an expression for desire for fundamental change. What is understandable is that social and political conflict is inevitable, normal and ubiquitous in all societies which comprise diversity. Whether these groups are defined by ethnicity, religion, politics or class, they have different needs, interests, values and access to power and resources. How we comprehend conflict generally has a critical bearing on our response in specific situations. If we regard it as intrinsically destructive, then our efforts will be directed towards suppressing or eliminating it. On the other hand, if we view it as normal and inescapable then the challenge lies in managing it in a constructive fashion, for instance, by using non-violent ways that enjoy the consent of citizens. The understanding shared in this paper is that the Church can do this; it can bring back justice, peace, reconciliation and national healing among victims of violence.

The paper as has already been highlighted stands on the Lederach's conflict transformation framework 
in analysing the role of the church in the search for peace, reconciliation and unity in Zimbabwe. According to Lederach (1995)

Conflict transformation is to envision and respond to the ebb and flow of social conflict as life-giving opportunities for creating constructive change processes that reduce violence, increase justice in direct interaction and social structures, and respond to real-life problems in human relationships.

Conflict transformation reflects a better understanding of the nature of conflict itself. In explaining conflict, Lederach asserts that conflict transformation does not suggest that we simply eliminate or control, but rather recognize and work with its "dialectic nature". By this he means that social conflict is naturally created by humans who are involved in relationships, yet once it occurs, it changes (i.e. transforms) those events, people and relationships that created the initial conflict.

Conflict transformation suggests that, when left alone, conflict can have destructive consequences. However, the consequences can be modified or transformed so that self-images, relationships and social structures improve as a result of conflict instead of being harmed by it. Usually this involves transforming perceptions of issues, actions and other people or groups. Since conflict usually transforms perceptions by accentuating the differences between people and positions, effective conflict transformation can work to improve mutual understanding. Even when people's interests, values, and needs are different, even nonreconcilable, progress has been made if each group gains a relatively accurate understanding of the other.

Lederach's conflict transformation framework is apt for this study because of its applicability in providing a coherent and better understanding of Zimbabwe's peace and reconciliation process in the transition period under the GNU. It acknowledges that dialogue and the promotion of mutual understanding are crucial ingredients for fostering peace unity and reconciliation. Transitional processes like the GNU offer political rivals an opportunity to work together and reach a better understanding of each other for the creation of mutually beneficial relationships. The church as a transformative institution is tasked with this role.

It has proved problematic to many pertaining to how a Church should be defined let alone what it really is. The controversy stems on whether a church is a building, a place where believers gather to worship or if the church is the people i.e. the believers who follow Christ. The word church as rendered in the New Testament comes from the Greek term ekklesiawhich is formed from two Greek words meaning an assembly and to call out or called out ones.

The New Testament uses the word 'church' in the following ways: a meeting of Jesus' followers, a gathering of believers that meet in a house, all believers in a particular locality, believers in a particular locality under the care of a group of elders, all believers everywhere (the worldwide church). In line with this, common elements are such that the church consists of a group of people, the group of people are followers of Jesus Christ and the church is a community in which God lives by his Spirit (Blackman:2007). The Church is an expression of the heavenly congregation here on earth. It is God's primary agent of transformation in the world.

There are two meanings derived from the notion "church". The difference between the uses of this word church is locality. For example, it can refer to a group of people meeting in a house or all believers everywhere. As the church is a community of people who follow Jesus Christ, it is appropriate that they meet with one another regularly. It is not possible for all Christians to meet together, therefore they meet together in smaller groups, usually in the area in which they live. The term used for this grouping is 'local church'. At the same time, all believers are members of the universal church (Blackman: 2007). The universal church is made up of every single person who has exercised faith in Jesus Christ for salvation, including members of every local church body throughout the earth (1 Corinthians 12:13; Ephesians 1:22-23)

The study will not look at the local church or the universal church for the former implies looking at every church as a single entity which is way too cumbersome while the later implies everyone in the whole world who is a believer in Christ which in turn, will affect the focus of this study as it concentrates only on Zimbabwe. Instead, the study uses the term church to represent a vast array of ecumenical bodies past and present that are in Zimbabwe. Ecumenical bodies in Zimbabwe include the Zimbabwe Council of Churches, the Zimbabwe Catholic Bishops Conference, the Evangelical Fellowship of Zimbabwe. These three bodies have come together in many instances in advocating for human rights and against the use of violence in Zimbabwe. It is through these bodies that the Church has been involved in the Zimbabwean crisis, particularly against the current repression and intolerance. The Church in Zimbabwe has fought for a democratic space in every arena of public life.

The question often posed by many concern the role of the institution of the church.The church is called to demonstrate the kingdom of God as a visible sign of his kingdom. The church should influence situations for the better, preserve good things and bring healing. In short the church can be understood as a transformative institution meant to change people's lives for the better.According to the Faith Gospel, God has met all needs of human beings in the suffering and death of Christ, and every Christian should now share the victory of Christ over sin, sickness and poverty. A believer has a right to the blessings of health and wealth won by Christ, and he or she can obtain these blessings of health and wealth won by Christ, merely by a positive confession of faith 
(Ranger: 1998). The role of the church is shaped along such lines. For instance, the Church can play a positive role in promoting the Democratization process. In many cases the Church has played a watchdog role by putting aspects done by the Government into questioning as a way of putting the needs of the people in the forefront. It is the mission and mandate of ecumenical agencies in Zimbabwe like the ZCC to promote peace and development in Zimbabwe. For instance ZCC's mission stipulates that:

We (the ZCC) have a God given Biblical and theological mandate to guide the nation and all leaders in making God's voice heard at particular times when He chooses to speak to His people on issues of justice, peace, reconciliation, poverty and the liberation of the oppressed (Luke 4:18-19). As the custodians and facilitators of God's mission, we are obliged to "stand up and proclaim" the will of God, whenever His people are faced with difficult situations that seem to deny them fullness of life (John 10:10). In the same way we applaud and encourage positive actions and developments. We continue to do so as in conformity with our calling through preaching the Gospel of truth, justice, peace and love as entrusted to us by the Lord Jesus Christ.

This has become the mandate of all ecumenical agencies in Zimbabwe. As part and parcel of this the Church in Zimbabwe has become involved in the peace and reconciliation process. The institution of the church has also played a role in social, political and economic issues. The role of the church in politics must not be questioned. Historical factors have also seen the church co-operating closely with the state; it has also become a strategic actor on issues of national interest and featured prominently in efforts to resolve the crisis that engulfed the country.

A government of national unity is a coalition government, designed specifically to accommodate all participating political players in governmental structures (Mukoma, 2008). This includes, the civil service, cabinet, diplomatic posts, the judiciary and in other instances, army, police and the intelligence arms. The logic behind this is that, equitable participation will diminish the potential for conflict and enhance prospects for national stability, integration and development. The assumption behind this logic is that conflict arises from mere exclusion of key political players in structures and processes of national governance (Chigora and Guzura: 2009). The joint exercise of power in principle enables conflicting groups to remedy long standing patterns of antagonism and discrimination, and to build a more just and stable society for all (O'Flynn and Russell: 2005). In addition unity governments as transition arrangements may provide the opportunity for the creation of constitutional review commissions, truth commissions and electoral reform which assist in the search for peace.

\section{Background to the Zimbabwe Conflict and the GNU}

The conflict in Zimbabwe is multi-dimensional. Some of its roots can be traced from the pre-colonial era through colonial times to the post -colonial period. The discourse focuses more on the background to the contemporary conflict. With independence in 1980, there was a change of authoritarian political power from the white minority rule to the black majority rule under the ZANU PF. This is clearly evidenced by what soon transpired.For instance, the new government marginalized and deliberately began to exclude those who it perceived to be its opponents. It speedily established a de facto one-party state through a campaign which has been known as the Gukurahundi massacres. The campaign was justified by its implementers as an attempt to stamp out dissident and terrorist activities which were allegedly being spearheaded by the main opposition party the Zimbabwe African Peoples' Union (ZAPU), led by Joshua Nkomo. ZAPU's members were mainly people of the Ndebele origin, which lends credence to the viewpoint that Gukurahundi was an ethnic-cleansing process by the ruling party (Kaulemu: 2010).Having succumbed to pressure and a growing concern for the loss of innocent life, ZAPU conceded to the ruling party's proposition for the formation of a government of national unity. In 1987, a Unity Accord was signed between the two main political parties ZANU (PF) and ZAPU, who merged into one political establishment called ZANU (PF). This effectively created a de facto one party state (Kaulemu: 2010).

Nevertheless, this de facto one- party state was not to last, as disgruntlement grew and political parties such as Zimbabwe Unity Movement and ZANU- Ndonga a splinter party emerged as voices that diverged from those of the establishment. Although recognized legally as democratic institutions, these parties received highhanded treatment from the government that victimized their membership and closed spaces for political campaigning and participation. Meanwhile, the ruling party and government had been losing popularity owing to their mismanagement of the economy, mass unemployment, growing poverty levels, corruption and the repression of dissenting voices.

In 1999, a new political movement, known as the Movement for Democratic Change (MDC) was formed. Also in that year, the government commissioned an inquiry to write a new constitution. Civil society, led mainly by the National Constitutional Assembly (NCA) and MDC, led a campaign against the government's proposed new constitution, saying that it gave excessive power to the executive and was merely designed to extend Robert Mugabe's term of office, as he had already ruled the country for two decades.In 2000 the government sponsored Constitutional Commission's draft constitution received a no vote in the national referendum. That defeat did not go down well with the ZANU PF government, as it perceived the rejection of 
its proposed constitution as a rejection of itself. This scenario sparked a series of reprisals against the opposition and against anyone who dared to dissent openly from the ruling party's leadership methodologies. During this period ZANU PF aligned war veterans and peasants violently occupied land belonging to mainly white farmers. This action incensed Britain, America and other western states that owned land and other economic interests in Zimbabwe. They responded by imposing sanctions which deepened the conflict and gave birth to a host of socio-economic and political problems in the state that have generally been referred to as the Zimbabwe crisis.

This crisis era has been characterized by illegitimate land seizures by government loyalists; the negative response or unwillingness of the state establishment to remove the unlawful land invaders; political violence and electoral violence, human rights abuses, democratic deficits, high unemployment, hyperinflation, poverty and untold suffering.

The crisis reached its crescendo following electoral violence in 2008 that resulted in the deaths of several supporters. The country's economy virtually came to a standstill and raising socio-political tension which left the country on the verge of civil war. To stem the crisis the MDC formations and ZANU PF signed the Global Political Agreement (GPA) on 15 September 2008 that paved the way for the creation of the Government of National Unity.

Under Article VII of the agreement the GNU was charged with national healing, integration and reconciliation for sustainable peace.

\section{A brief history of the Church in the conflict and peace processes before the GNU}

In the early years of colonial rule the relationship between Christian missionaries and the colonial settlers and administrators was close. The church supported the oppressive colonial policies and structures which enhanced the worth of the bourgeoisie and diminished the social status of the African (Hastings: 1982).

The Church did not condemn colonial brutality and exploitation of the Africans but instead appeared to be a silent partner in the oppression of the African people or acquiesced to the inhuman treatment given to the black majority population until the most violent and final phase of colonialism was reached. It was jerked into action by the bitter criticism it received from African nationalism, and the revulsion it felt to the illegal and oppressive political order created by the Unilateral Declaration of Independence in 1965 under the Rhodesia Front Party (Linden: 1980). Due to criticism the Church received from African Nationalists, the year 1965 became a turning point in the life of the Church in Zimbabwe as it began to take a stand against the inhuman and oppressive treatment of the black majority and started to support their struggle (Linden: 1980). The church began to advocate for the promotion of democracy and human rights. It castigated and challenged the repressive government of the Rhodesia Front.

Contributions from the Catholic Justice and Peace Commission and the involvement of the International Ecumenical bodies, such as the Lutheran World Federation and the World Council of Churches (WCC) helped to create a positive attitude towards the Church and religion as a whole. They contributed to the struggle for liberation through their support for refugees and the provision of scholarships (Linden: 1980). Although church officials did not take an open stand in support of the armed struggle, the ordinary Christian in the village and many individual church leaders, identified with the struggling masses.

The formation of the African National Council in December 1971 was out of the support of the Churches against injustice. The establishment of Christian Care 1967 was also out of the work of Churches in an endeavor to promote justice. Christian Care was non-political in the sense that it did not support nor "discriminate according to political party, ethnic or tribal group, religion, class or color"(Linden: 1980). This was an important aspect as it attended to the needs for both races, the whites and the blacks. This demonstrated the church's commitment to the promotion of justice and peace for everyone. It should however be noted that the church was not a homogenous body. There were some sections of the church body like the Dutch Reformed Church that supported oppressive colonial policies that were responsible for the suffering of the Africans.

In 1979, the Church took a major political initiative by pleading with all political groups involved in the Lancaster House negotiations calling for the termination of the war and reconciliation and national unity. Despite the pleas by the Church for peace and unity they proved elusive in the newly independent state of Zimbabwe. The Church was again engrossed in the quest for peace in the early 1980s through the Catholic Commission for Justice and Peace with compiling government atrocities in Matabeleland where a civil was raging between dissidents and the government. The independence era also witnessed the Church team up with civic organizations and associations which challenged the repressive measures instituted by government.

\section{The Church in the GNU Peace and Reconciliation Process}

Zimbabwe has been engulfed in violence and crisis for more than a decade. The origins of the crisis are varied making it impossible to present a single dimension conflict resolution strategy. An understanding of the underlying cause of a conflict is crucial to the effective resolution of conflict. Since the Church is composed of various groups of society that have diverse backgrounds and bring with them various skills and expertise this 
makes it perhaps the best institution to lead the peace and reconciliation process.

Under the GNU the Church should be in the forefront of de-escalating the crisis in Zimbabwe. However, divergent views on the role of the Church in responding to the challenge of healing and reconciling Zimbabweans in the aftermath of Zimbabwe's 2008 political violence have been noted. Differences in how the peace and reconciliation can be promoted have not only been found amongst political players but have also been found in the church resulting in deep divisions which have hindered church efforts aimed at uniting the country. According to Blackman (2007) these differences have ranged from uncompromising condemnation and rejection of Mugabe's regime through to non-confrontation and even practical engagement with the ruling party. For instance, some leaders of independent African initiated churches have largely thrown their weight behind ZANU PF while traditional church structures have been ambivalent about getting involved in the political issues while the Catholic Church has been critical of government's repressive policies and actions. The above mentioned ecumenical groups have taken such positions but most churches have fallen into the pit of political appeasement at the expense of maintaining the integrity of the Church making them officious bystanders caught in between two political gladiators at each other's throats instead of transforming relations between them (ZCBC et al 2006).

The role of the Church in national healing and reconciliation has been greatly undermined in the transition period because of close links with civil society. Civil society has been accused by the ZANU PF of working in cahoots with the west to effect regime change. The Church together with civil society has been preaching democracy, advocating for human rights and good governance. This discourse is associated with the former opposition although this does not mean that churches have been partisan.The close association with civil society in an era of strained relations between state and civil society has blunted church efforts of reconciling divided Zimbabwean society.

The role of the Church is to be the conscience of society. As the moral guardian of society, it should interpret to largely Christian Zimbabwe Biblical standards of justice and righteousness and articulate what is wrong in Zimbabwe and why it is wrong and then advocate for an end to oppression (Blackman 2007). Under the GNU it should be providing leadership and guidance and playing a key role in promoting national healing and reconciliation as opposed to the situation where it has been pushed to the margins of the whole process. Under Article 6 of the GPA the government was charged with the writing of a new constitution. Churches through the ZCC made their submissions but the constitution that was adopted barely reflects the input made by the church. The Church's input was sacrificed at the altar of political expedience.

Prior to the creation of the GNU the Church tried to foster unity through negotiation and diplomacy with the ruling party ZANU PF party. In the year 2006 Bishop Peter Nemapare led a delegation of Churches to meet the president to chart a way forward regarding the resolution of the crisis in Zimbabwe which was fissuring society. The delegation submitted the church's response to the crisis in document entitled the "Zimbabwe We Want:Towards A National Vision For Zimbabwe". The document spells out the Churches view of problems bedevilling the country and how they could be resolved. Efforts by Nemapare's group were complemented by Andrew Wutawunashe's nationalist 'Faith for the Nation' campaign. His campaign sought to infuse Christian ideals into the national body politic. For him, it was vital for all Zimbabweans to put aside their political differences and to work together for the good of the nation (Chitando, 2011).

Under the GNU, the church has not been provided with the space to effectively participate in efforts to attain peace and unity. The Zimbabwe Catholic Bishops Conference in 2009 pointed out that the problems afflicting the GPA and the crisis faced by Zimbabwe were not only political and economic but first and foremost a spiritual and moral crisis (www.zimbabweinstitute.net/.../Role\%20ofthe\%20church\%20book\%). They argued that the problems and crisis could only be resolved if the people of Zimbabwe confessed their transgressions and fully accepted each other and commited themselves to work together in solidarity, justice and peace.

The Church has been seeking to restore harmonious racial co-existence however efforts aimed at this have been frustrated by radical elements in the inclusive government. They are averse to racial reconciliation which they view as a betrayal of the people of Zimbabwe and a stepping stone to neo-imperialism and recolonisation. Church efforts directed at fostering race reconciliation have put it under scrutiny. It is now perceived as the enemy of the State and has also been accused of aligning with drivers of regime change. Against this backdrop the effectiveness of the Church as a promoter of democracy and instrument of national healing and reconciliation has been compromised. It has been cowed by hardliners and has become cautious about taking an overt political stand regarding the crisis in the country.

The Church has been used as an instrument by which political formations have been able to propagate their views and garner support ahead of elections. Church services and meetings have offered political contestants the platform to do so. The net effect has been to divide the church into two broad groups - those in favour of President Mugabe and those opposed to his continued grip on power. For example, independent African initiated churches such as the Zion Christian Church and the apostolic churches like the JohanneMarange have urged their members to support the President while the likes of Bishop Levee Kadenge 
and SifisoMpofu of the Christian Alliance, Bishop Anselm Magaya of the Zimbabwe National Pastors' Conference apparently sympathise with the former opposition and have joined it in denouncing government repression (Chitando 2011).

The Church needs a paradigm shift so that it can transform its humanitarian and development arms into instruments that promote healing and reconciliation of the Zimbabwean people. Given its massive social tentacles the church is better posed to understand conflict in human relationships. Peace and reconciliation can only occur if those affected by conflict are aware of the underlying causes of the conflict, its lifecycle and management. Through training pastors and lay leaders in congregations and communities the Church could disseminate skills and knowledge in areas of conflict prevention, management, peace building and meaningful national reconciliation. In one way or another every Zimbabwean is linked to a person who goes to Church as such, these skills could permeate society and cascade down to the generality of the population.

The Church directly or indirectly through its influence on the lives of people in society on a daily basis fosters peace and reconciliation. As a way forward in the transition period, there are things that the church can do that require little or no funding. Together Churches with their humanitarian and development arms can make a difference in the lives of communities as they strive to find peace and harmony after violent conflict. The Church is bigger than the political figures and political parties and other institutions bent on gaining control of the levers of the state. On issues of reconciliation and healing the Church should take the leadership role by initiating and calling the nation to a process towards forgiveness, reconciliation and healing through dialogue at grassroots levels. The Church should thus be empowered to become the instrument of peace, unity and reconciliation which are the cornerstones of nation building and development in Zimbabwe.

The Church is widely regarded as the bedrock of social integration, the cement of the social order and the moral compass of the nation. Under the GNU the church has thus been relegated to an institution that merely focuses on the Church's social mission of saving souls and the provision of humanitarian services through caring for the sick, elderly, orphaned and widowed and responding to emergencies by providing material support to victims of starvation and violence which happens to be a parochial understanding of the mission of the church.

\section{Conclusion}

During the transition the Church should have taken this opportunity and the largely violence free atmosphere that was prevailing to seek resolution to the major sources of conflict on the Zimbabwean political landscape such as: land, micro-economic policies, constitutional debate, electoral framework, human rights, governance. The discourse has however revealed that the involvement of the Church in political matters was undermined and reduced to mere rhetoric under the GNU. The Church was marginalized by political gladiators from effectively influencing the peace and reconciliation process and charting the political trajectory of the country. In light of this most churches decided against confrontation but chose the path of constructive engagement with the inclusive government. The partner the church chose to work with unfortunately was embroiled in hegemonic struggles and did not share the same vision and goals as that of the Church encapsulated in the Zimbabwe We Want document of 2006. It is therefore imperative that the Church wakes up to its role in the social, political and economic affairs of Zimbabwe in a more comprehensive way if peace, unity and reconciliation are to be achieved in Zimbabwe.

\section{References}

[1]. Badza, S., and Chigwida, M. (2005). Reconciliation in Zimbabwe the Next 25 Years: Harare: Benaby Publishing.

[2]. Blackman R. (2007) Partnering with the Cocal Tearfund 2007:tilz.tearfunf.org/webdog/tilz/Roots/.../Church/ROOTS\%2011\%20E.PDF
Bloomfield, D. (2003)Reconciliation: An Introductionin D. Bloomfield, T. Barnes and L. Huyse (eds) Reconciliation After Violent

[3]. Bloomfield, D. (2003)Reconciliation: An Introductionin D. Bloomfield, T. Barnes and L. Huyse (eds) Reconciliation After Violent
Conflict A Handbook. Stockholm, Institute for Democracy and Electoral Assistance.

[4]. Cheru, F. (2002). African Renaissance: Roadmaps to the Challenge of Globalization. London: Zed Books.

[5]. Clark, P. (2008). The Rules (and Politics) of Engagement: The Gacaca Courts and Post-Genocide Justice, Healing and Reconciliation in Rwanda in P Clark and D. Kaufman (eds) Transitional Justice, Post-Conflict Reconstruction and Reconciliation in Rwanda and Beyond, Oxford: Oxford University Press

[6]. Chigora, P.\&Guzura,T.(2009) The Politics of the Government of National Unity (GNU) and Power Sharing in Zimbabwe: Challenges and Prospects Paper presented at the European Conference on African Studies, June 4-7, Leipzig.

[7]. Chitando, E. 2011 Prayers, politics and peace: Church's role in the Zimbabwe's crisis, OSISA. http:/www.osisa.org/openspace/Zimbabwe/prayers-politics-and peace-role-zimbabwes-crisis

[8]. Galtung, J. (2001) 'After Violence, Reconstruction, Reconciliation, and Resolution:

[9]. Coping with Visible and Invisible Effects of War and Violence' in M. Abu-Nimer

[10]. (ed.) Reconciliation, Justice and Coexistence: Theory and Practice, Lanham, Maryland: Lexington Books

[11]. Galtung, J. (1989)Peace and Development in the Pacific Hemisphere. Honolulu:University of Hawaii Institute for Peace.

[12]. Galtung, J. (1990) 'Cultural violence', Journal of Peace Research, 27:3, 291-305. London: Sage Publications.

[13]. Hamber, B. (2003) 'Healing' in Bloomfield, Reconciliation after Violent Conflict: AHandbook, Stockholm, IDEA

[14]. Hastings, A. (1982) A History of African Christianity 1950-1975, Cambridge University Press $2^{\text {nd }}$ Edition

[15]. Kaulemu D. (2010) Political Participation in Zimbabwe. The African Forum for Catholic Social Teaching, Harare 
[16]. Kriesberg, L. (2006) "The Evolution of Conflict Resolution" in Bercovitch J and William Z (eds) The Sage Handbook of Conflict Resolution.http://www.sage.handbook/conres/html

[17]. Lederach, J. P. (1995) Preparing for Peace: Conflict Transformation Across Cultures. Syracuse University Press

[18]. Mark, I. (2007) 'Reconciliation: bridging theory to practice: a framework for practitioners' The Hague, Centre for Justice and Reconciliation

[19]. Machakanja P (2010) National Healing and Reconciliation in Zimbabwe: Challenges and Opportunities. Institute for Justice and Reconciliation, Wynberg Mews, South Africa

[20]. Mukoma WN (2008). A caricature of democracy: Zimbabwe's misguided talks in The International Herald Tribune @ http://www.iht.com/articles/2008/07/25/opinion/ednug.php?page=2

[21]. O'Flynn, I and Russell, D (2005) Introduction: New Challenges for Power-Sharing, in I O'Flynn and D Russell Power-Sharing: New Challenges for Divided Societies (eds) London: Pluto

[22]. International Institute for Democracy and Electoral Assistance.1998a. Democracy Forum: Content: "A Culture of Democracy: The Issues". http://www.int idea.se/97df/df98/df3.html.

[23]. International Institute for Democracy and Electoral Assistance. 1998b. "Democracy Forum: Press Kit: Reconciliation and Justice". "The Path Toward Reconciliation and Justice," http://www.int idea.se/97df/presskit/reconciliation.html.

[24]. Ranger, T.O. (1998) Religious Movements and Politics in Sub-Saharan Africa, African Studies Review

[25]. ZCBC (Zimbabwe Catholic Bishops Conference), EFZ (Evangelical Fellowship of Zimbabwe) and ZCC (Zimbabwe Council of Churches). 2006. The Zimbabwe We Want: Towards a National Vision for Zimbabwe: A Discussion Document. 15 September 2006. Harare: ZCBC, EFZ and ZCC

[26]. (www.zimbabweinstitute.net/.../Role $\% 20$ ofthe $\% 20$ church $\% 20$ book $\%$ s). 